\title{
History is returning to design
}

\author{
Alexander Tzonis \\ TU Delft \& Liane Lefaivre, Universität für angewandte Kunst, Wien
}

\begin{abstract}
I looked up "history" in the dictionary. The definition I liked best was, "study of the past." Now any number of things can be the study of the past. Archaeology is the study of the past; it has more specific definitions than "history" does. How you choose to study history-whether as mainstreams, as isolated events, as typologies, etc.-however you choose to study it, there is no first rate and secondrate history implied by how you choose to study it.
\end{abstract}

Lawrence Speck.

When any field is undergoing development, it invents a simplistic framework on which things are hung. Then as the field expands, as it develops, the repertory begins to expand. I think we are moving out of that central spine on which everything was hung. We are moving into the study of social relationships, political relationships, vernacular, etc., and beginning to absorb more. The profession of architectural history is expanding. Many of these problems are resolving themselves.

Dora Wiebenson.

Whatever you propose to do, you have to make your own slides. Which means you have to have money to travel. I am struck by the fact that I teach courses to hundreds of students each yearmainline, bread-and- butter courses that go on year after year-but if I ask the university for the opportunity to travel, to see the buildings I am supposed to know something about, and to photograph them in ways that are appropriate for use in my lectures, they think all I am after is a summer in Europe.

Richard Betts.

While I have questions about this characterization of past historical scholarship, I generally agree with the authors' aims. The danger in their proposed method is that it threatens to pull the researcher away from the object toward an analysis of society, rather than bringing relevant data to the object under investigation.

Stephen Tobriner.

$\square$ bjects are not created in response to pure functional necessity, nor do they arise in the mind of the designer from an instinctual urge to create. They are the out- come of preexisting conceptual frameworks whose structure is socially determined and whose aim is social. Buildings, cities, parks, and transportation networks are products of design decisions. These are implemented or enforced through institutions. Ultimately, interests operating in society support the conceptual frameworks and control the institutions.

In the final analysis all uses of design are social, all serve to create, to maintain or to dissolve human dependencies. But the functions of conceptual frameworks, institutions and interests are not always readily visible. Neither is their long-term impact on human relations. Whether by intention or by accident, these workings may be lost or buried. No other discipline can retrieve them as well as history. Any study of the social use of design must focus on the interactions which connect, over time, interests, institutional structures, conceptual frameworks, design decisions, design products and human relations.

The interaction between human relations and design products seems to be the subject of extensive investigations in environmental psychology, ergonomics and cultural anthropology. The fact is that those studies in most cases do not analyse in depth the social use of design. The reason for this stems from the methodological constraints inherent in the methods adopted in those fields. They provide a narrow understanding of the relationship between design and society, relying as they do on the methods employed in the physical sciences. As engineers 
record the properties of materials by observing their behaviour under certain conditions, so these social scientists observe the behaviour of the users of the built environment in order to evaluate the design product.

In this respect they continue the tradition of Locke by viewing all phenomena of the world as "materials" and of relying on "observation" to acquire knowledge. By grafting the concepts and principles of mechanics onto design, this approach concentrates too narrowly on the observable behaviour of the user of the man-made environment and confuses description with explanation. By failing to take into account the dimension of time, it divorces the products from the forces that generated them and isolates the behaviour of the user from the overall context of human relations and of conditions that determine the system of rules within which the user perceives, chooses, and acts.

This is not to say that empirical data have no value in the study of design. It suggests rather that, in this case, the data assembled and the model used for organizing them are not sufficient to yield significant conclusions about the social use of design. No amount of analytical manipulation of those data can redeem these faults.

Similarly, there are shortcomings to the study of the man-made environment as "habitat." This approach borrows from the methodological and theoretical constructs of biology and ecology. It presents culture as an extrapolation of "animal tradition" differing from it "only in degree"1 and design objects as extensions of the human body, products of individual needs of the human organism in its effort to adapt to its milieu, tools created by the interaction between the human physiology and the natural environment. These constructs, like the social engineering and the behavioural sciences models, offer descriptions as explanations. Although they do not exclude the dimension of time from their analysis of design, they ignore the social use of design products in the past, presupposing that humans and biological organisms operate similarly. They are unable to see design objects as part of an artificial world resulting from conceptual frameworks and institutions based on interests. Neither the model of mechanics nor the model of biology can be extended or applied by analogy to the domain of the man-made environment, because to understand how the man-made environment operates and how it affects human relations requires a perspective which only history can provide.

Not every kind of history can explain design. An insular history, based on categories that ignore the original interests, concepts and institutions, which determine the design decisions, can only be limited, not to say misleading. Such is the case, for example, with the architectural history developed by Sigfried Gideon, in a tradition reaching back at least as far as Choisy and Viollet Ie Duc. ${ }^{2}$ The works of architecture of the past were perceived as springing from a primitive anticipation of the modern technology, the conspicuous search for new space and construction arrangements to demonstrate the novelty of construction techniques and materials and the legitimacy of their use. Such thinking was a-historical both in its contempt for the reasoning behind the objects of the past and in its ignorance of their former uses. False, such interpretations also contributed to the environmental devastation caused by modern architecture by providing it with a historicist license to freely replace the old urban fabric with new structures.

A very different approach to history of design is that of the stylistic school. It perceives the designed products not as answers to functionalist problems but as aesthetic creations asking only to be looked at and appreciated ${ }^{3}$ Early studies in this tradition endowed artistic creation with powers all its own. In order to account for the variety among design products, the amateurs of fine objects claimed that a style developed in cycles, that it "blossomed" and "withered" like 
a "plant." The cyclical theory of history can be traced back as far as Plato's Laws. The broad application of this model tended to be open to idiosyncratic interpretation and conjecture. ${ }^{4}$ And so it was for Winckelmann, for whom the reason for the "decline" of Greek art was that its "images...had been formed in all conceivable shapes and attitudes and it had become increasingly difficult to think of new ones." 5

Heinrich Wölfflin is considered the leading opponent to the reaction to this cyclical model of history. He accused his predecessors of "never (having) systematically founded" their assumptions. ${ }^{6}$ He undertook the creation of a sounder basis for the discussion on art; a kind of categorical framework, analogous to the one Kant developed in philosophy through his priori categories. Wölfflin postulated that changes in style come in succession and "they oscillate in an orderly way, between opposite 'forms of vision,' " which are the following: linear versus painterly, parallel surface versus diagonal depth, closed versus open, composite versus fused, clear versus unclear. "Art history," Wölfflin stressed, "is more than a 'translation of life' (Taine) into pictorial terms ...which attempts to interpret every style as an expression of the prevailing mood of the age. ... The moment we want to apply artistic standards of judgment in the criticism of works of art we are forced to try to comprehend formal elements which are unmeaning and inexpressible in themselves and which are developments of a purely optical kind."

Wölfflin's investigation of history through abstract categories of pure visibility presupposed that the purpose of a design object was to create a visual aesthetic impact. It also rested on the assumption that such categories were universal. From this it followed that the visual properties of the object, its stylistic traits, fully expressed its meaning. Consequently only formal factors were incorporated into the analysis. Moral, religious, philosophical and political significations were abstracted, as were emotion and technique.

Alois Reigl proposed a method of historical analysis based on an a priori structure similar to Wölfflin's in that it also included a list of alternating abstract visual polarities. The categories themselves, however, were different: tactile versus visual, the presentation of the object isolated versus being placed in space, objective versus subjective. ${ }^{8}$

Although Riegl tried to develop a universal set of abstract categories, his analytical tools were still, like Wölfflin's, bound to the objects at which he aimed his analysis, those of the Ancient Near East and of the Roman and Early Christian periods. Moreover, Riegl based his analysis on the same assumptions as Wölfflin: that the purpose of design objects is to create a visual aesthetic impact. To explain the creation of design objects, he developed the concept of Kunstwollen following the theory of Schopenhauer that every human action is the product of forces, that every art relates to a will and that every stage of every art corresponds to an advancement of will. To explain how visual characteristics changed in time, Riegl asserted that periodic changes in style were the result of the pulse of the mentality of the time, what he called the Denkweise.

Whereas Wölfflin's and Riegl's stylistic analyses relied on formal aspects versus the content-bound or emotional characteristics of visual elements, Theodor Lipps and his follower, Wilhelm Worringer, stressed the opposite: expression and emotion. Forms have an impact on the viewer, they claimed, because he recognizes in them the expression of feelings, because he himself becomes incorporated in the forms or because "he unconsciously, [feels] inwardly the process of their formation." Forms are the outlet of "inner feelings," "the expression of spiritual unrest," "the liberation of [a] sense of vitality." Departing from the same suppositions as Wölfflin and Riegl and under the same influence of Schopenhauer about the aesthetic purpose 
of design products, Worringer stressed that while "the will to form remains the same throughout the entire development," the differences in style are the results of an interaction between "stages" in feelings, in excitement, in pathos which dominate man in a period, and the kinds of material available which permit the expression of those feelings through works of art.

The stylistic analysis approach to the history of design had two basic limitations. The first was that although the methods strived to be universally applicable, they always remained bound to the set of objects from whose observation they emerged. As historians shifted their focus to new areas, the accepted stylistic categories met with operational difficulties since they could not account, even as criteria for classification, for all periods and places. New categories had to be advanced, always in keeping with the pre-supposition that the purpose of a design object was to foster a pure, abstract visual aesthetic impact. The second limitation of this approach to design history was its failure either to identify the actual use of the design object in a given period or to ex- plain the general phenomenon of the production of the man-made environment. This failure stemmed from the inability of the field to overcome the boundaries of its original program that is, defining the role of the design historian as an assistant to the amateur and the collector.

The historian of design was curator, connoisseur and author of catalogues raisonnes in which visual characteristics helped to date, to assign origin, to determine authenticity, to label and to appraise works of art. At the beginning of the nineteenth century, connoisseurship split into archaeology and art criticism. The archaeologist, and we refer here to the museum expert utilizing the lesson of philology, developed techniques and identified attributes for constructing taxonomies of design products of the past-with little concern for the tastes and preferences of his day and for the value of the objects as a collector's item. As a result, the archaeology of the last century, the new scientific connoisseurship, became a discipline as organized and challenging as that of mineralogy or botany, and equally indifferent to the problem of explaining the objects described and classified.

The design historian developed categories of classification. But the urge to evaluate was always present in his analysis. For this reason, his categories were dominated by contemporary aesthetics and a concern for the creation of new products. They reflected the taste of the day rather than the attitudes and sensibilities of the past. Winckelmann's categories were closely linked to the Neoclassical movement, Ruskin's to' the Pre-Raphaelites, Wölfflin's to the movement towards abstraction and Worringer's to expressionism.

The concern for evaluation was not without consequences. As Marc Bloch so sharply pointed out, "The habit of passing judgments leads to a loss of taste for explanations." This holds true however broad the criteria of evaluation, including moral evaluation, because as stylistic analysis presupposes that design products ought to have an aesthetic visual impact, the moral point of view recommends a certain state of human affairs. In both cases the presuppositions may be irrelevant to the period under discussion, which suggests that the acceptance of the task of evaluating, of "criticizing" past design products by the design historian, may be invalid unless a universal standard of evaluation is proven to exist. This holds true for either stylistic or moral criticism.

In order to analyse in depth the design process involved in, for example, the production of the eastern facade of the Louvre during the reign of Louis XIV, one must explore it in the context of the external conflicts of the absolutist regime and of the internal conflicts and coalitions that involved the nobility, the court, the mercantile class, the guilds and the peasantry. To appraise the actions of any of these groups as morally good or bad impedes any further explanation of 
the social relations, events or objects in question. An evaluation of this type is not very different from measuring the design of the Louvre in terms of any other evaluative standard, such as meeting the specifications of 'structural efficiency, economic construction, micro-climatic control, the compositional criteria of the Beaux Arts or Marcel Duchamp, the ideals of the socialist revolution, or humane values with respect to the small number of workers it mobilized. This can be an absorbing type of exercise, but it can hardly inform us as to why the Louvre was designed the way it was and what its erection meant to the contemporary society. By getting involved with evaluations of past products, historians of design have committed the fallacy classified by David Fischer as "false analogy." They have looked at the decisions, the actions and the products of the past as answers to questions of the present. To borrow from a similar criticism, which Collingwood made of the anachronistic "realist" attitude of his colleagues in philosophy, it is comparable to objecting to the poor descriptions of steamers by the ancient Greek authors who were in fact, referring to triremes. ${ }^{11}$

In his intriguing essay on Gothic architecture, Erwin Panofsky did try to develop an analysis of design that was free of the evaluating predisposition of historical criticism. He compared the dominant scholastic writings of the period with the cathedrals, the "new style of building." 12

He found a correspondence between the theological argumentation in the texts and architectural elements. Because the structures of both presented a similar development, he concluded that the modes of thinking and the habits of designing were shaped in a similar manner.

But the essay on Gothic architecture used as a base the false supposition that de- sign products are of the same nature as thoughts. For this reason, Panofsky's conclusions are limited - despite the fact that the material brought together is, as a result of Pan of sky's formidable erudition, bountiful and the pattern of correspondences striking. But if the presuppositions behind them are invalid, those elements cannot in themselves lead one to a valid conclusion. From the outset, Panofsky warned the reader of the pitfalls in the pursuit of such "parallels," but he was unable himself to resist the temptation of drawing inferences about "palpable and hardly accidental concurrence" from such analogies. As a result, the "unities" he established between design products have, at their best, a classificatory value; and the essay fails to provide a historical explanation for the genesis of the form that was true to the period.

One can also find efforts to establish analogies between texts and design products of the same period in discussions of content rather than formal characteristics. These studies describe texts and buildings as expressions of a common spirit of the epoch, a common worldview. A typical example of this approach to the history of design can be found in Pevsner's analysis of Renaissance architecture. "Architecture is not the product of materials and purposes - nor, by the way, of social conditions - but of changing spirits of changing ages. It is the spirit of an age that pervades its social life. ...The Gothic style was not created because somebody invented ribvaulting, [it was] worked out because a new spirit required it." 13 Based on such assumptions, Pevsner arrived at the speculative conclusion that the "central plan" of the Renaissance church was "the symbol of worldliness" and of " the spirit of Humanism." In fact, as other studies have factually demonstrated, expressing the spirit of the epoch was not a motive for architecture in either the Renaissance or the Gothic.

To study such anachronistic histories of design may be interesting and rewarding. Some designers may find in them stimulation for expanding their formal vocabulary. This is the purpose of a large number of courses around the world in the history of architecture. Such anachronistic 
use of history - which we may call heuristic - helps students become more inventive by exposing them to a great variety of formal, spatial arrangements, which have been developed through time. But we have to be conscious that such use of works of the past, while it may produce fascinating typologies and intriguing cabinets des curiosites of architectonic objects, has strict limitations. Anachronistic history may easily lead us to think very much like those "German soldiers in 1914," written about by Bloch, who "envisioned .... as so many loopholes prepared for snipers ...the innocent contrivances of the masons ...on the fronts of a great many Belgian houses..." that, in fact, had been" designed to help the plasterers in setting up their scaffolding."

In the end, the findings of stylistic analysis and the conjectures about the formal expression of the spirit of the time can be applied only to those works, which have been conceived as stylistic compositions or as statements expressive of a period. Visual uniformities do form clusters at certain locations in space and certain periods in time, but such phenomena do not always arise from stylistic considerations and cannot always be explained through stylistic categories. To understand a design product, one must find the document that reveals its meaning, its real use.

In one of his most vivid passages, Emile Male recounts his chance discovery of Cesare Ripa's Iconologia from 1593 and, therein, of the key to Bernini's personification of Truth in the Villa Borghese and to much of the 17 th century's allegorical representation. ${ }^{14}$ Ripa's Iconologia is not unique. A large number of documents can be found in which meaning is matched with the design of physical objects, one of the most ambitious of these being Emanuel Tesauro's $I l$ Cannocchiale Aristotelico. Borrowing concepts from Aristotle, Tesauro tried to build a general system to describe and prescribe the total artificial world as a universe of objects which are meant as carriers of meanings, as words of a discourse or, as it was called in the 17th century, an Argutezza. All objects, whether "Natural Bodies," "Artificial Bodies," or "Rhetorical Images," stood as "names" and "oracles." All compositions with those objects, served as "sentences" in a "language" subject to "interpretation." Design was seen as a process of coding. It is only with this conception of the man-made environment in mind - as a symbolic universe - that history of design can be envisaged as an activity of decoding.

This was the dominant direction taken by the Warburg Institute under the guidance and inspiration of Aby Warburg. In the first issue of the Institute's journal in 1937, Jacques Maritain sketched a program for the study of culture and its development through a "study of signs and symbols." 15 The work at the Institute echoed a contemporary construct of Ernst Cassirer, which interpreted and analysed culture exclusively as composed of "symbolic forms," a "system of signs," and a "world of symbols." 16

Recent attempts to reduce the history of design to a history of signs and codes or to a history of relationships between the so-called signifier and signified should be seen as a generalization of previous efforts of the iconological approach. ${ }^{17}$ This direction, under the name of semiology, having been substantially influenced by Saussurian linguistics, extended iconological analysis with the notion of syntax, grammar and other morphological characteristics of language in addition to the meaning. ${ }^{18}$ But a history of design based exclusively on iconological documents and semiological considerations, although applicable to certain works, has its own limitations. It can relate only to products that have been constructed as symbolic objects, whose only purpose is to signify.

In the development of culture, a large number of man-made objects are not made simply in order to carry a meaning. In general, machines or instruments derive from decisions and conceptual systems, which are not to be found in manuals of iconology or any coding system. 
Similarly with a factory, an airport, a regional plan, a camp, a bastion by Vauban, or the projects for a new Hotel Dieu designed by the Academie des Sciences just before the French Revolution - the decisions that shaped them, and the norms inside those decisions, destined them not for signification but for the production of utilities.

One must be careful not to confuse the case of a machine or an instrument used as a symbol, or as a signifier in a painting or as an objet trouvé on a podium in a gallery, with the case of the same machine or instrument performing productive operations. Similar confusions arise when a machine comes to signify the social or economic position of its possessor in addition to fulfilling its role as a producer of utilities. Neither of these signifying functions detracts from the fact that machines and instruments can be made to produce energy exclusively, and not significations. A similar argument can be made that ritual props of archaic societies are not pure signifiers but stand between signifiers and machines as ancestors to both, and are different from both.

After all that has been said about the limitations of the stylistic, iconological and semiological approaches, it is appropriate to recall the remark Wölfflin made in 1888: "We still have to find the path that leads from the cell of the scholar to the mason's yard." It appears that a more universal history of design is needed to accommodate the totality of design products: the machines, the objects of divination, the aesthetic objects and the icons. A broader range of documents must be explored, no matter what type of thinking they reveal and regardless of the use of the object to which they relate.

\section{Editorial Note:}

This article has been originally published as:

Tzonis, A., \& Lefaivre, L. 1980. History is reurning to design, JAE 34(1), 7-10.

An earlier version was delivered as a paper presented at the Art History Institute, Utrecht, The Netherlands 16 May 1977.

\section{Notes}

1 Wilson (1975: 168)

2 Giedion, S (1941)

3

(1)

For an edifying discussion on the notion of style, see Shapiro, M (1963)

Nisbet, R (1969)

5 Winckelmann, (1764)

$6 \quad$ Wölfflin, (1888)

7 Wölfflin, (1952).

8 Riegl, (1908)

9 Bloch, (1949)

10 Fischer (1971).

11 Collingwood, (1939)
12 Panofsky (1951: 4)

13 Pevsner (1943: 17)

14 Male (1945).

15 Maritain (1937)

16 Cassirer (1923)

17 Schefer (1969); Jencks \& Baird (1969).

18 Barthes (1967): Eco (1968: Saussure (1959) 


\section{Works cited}

Barthes, Roland. 1967. Elements of Semiology, London: Cape.

Bloch, Marc. 1949. Apologie pour I'Histoire, ou Metier d'Historie.

Cassirer, Ernst. 1955. Philosophe der symbolischen Formen, Berlin, 1923, reprinted as The Philosophy of Symbolic Forms. translated by R Mannheim, New Haven: Yale University Press.

Collingwood, R.G. 1939. An Autobiography. London, Oxford University Press.

Eco, Umberto. 1968. La Stuttura Assente. Milano: BomPiani.

Fischer, David H. 1971. Historian's Fallacies. New York, Harper \& Row.

Giedion, Sigfried. 1941. Space, Time and Architecture. Cambridge, Harvard University Press.

Jencks, Charles and Baird, Geoge. (eds.). 1969. Meaning in Architecture. New York, Braziller.

Mâle, Emile. 1945. l'Art religieux du XIIe au XVIIIe siècle.

Maritain, Jacques. 1937. Sign and Symbol, Journal of the Warburg lnstitute (1).

Nisbet, Robert. 1969. Social Change and History. New York: Oxford University Press.
Panofsky, Erwin. 1951. Gothic Architecture and Scholasticism. Latrobe: Archabbey.

Pevsner, Nikolaus. 1943. An Outline of European Architecture. London: Murray.

Riegl, Alois. 1908. Die Enstehung der Barockkunst in Rom: Vorlesungen aus 1901-1902. Wein: A Schroll.

Riegl, Alois. 1901. Die spätrömische Kunstindustrie nach den Funden in Österreich-Ungarn. Wien: Osterr Staatsdruckerei.

Saussure, F. 1959. Course in General Linguistics. London: P Owen.

Schefer, L. 1969. Scenographie d'un Tableau. Paris: Editions du Seuil.

Shapiro Meyer. 1963. Style, Anthropology Today, ed. A L Kroeber. Chicago: University of Chicago Press.

Wilson, E.O. 1975. Sociobiology. Cambridge: Harvard University Press.

Winckelmann, J. 1764. Geschichte der Kunst des Altertums. Leipzig.

Wölfflin, H. 1952. Classic Art. London: Phaidon.

Wölfflin, H. 1888. Renaissance und Barock. Miinchen. 